日植病報 $49: 471-480$ (1983)

Ann. Phytopath. Soc. Japan 49: 471-480 (1983)

\title{
Effect of Isoprothiolane on Pyricularia oryzae Cavara (I) Cell Wall Regeneration of Protoplasts*
}

\author{
Hiroshi Ishizaki**, Akira Yajima**, Mitsuru Kohno** \\ and Hitoshi $\mathrm{KUNOH}^{* *}$ \\ 石崎 寛**・矢島 明**・河野 満**・久能 均**:イネいもち病菌に及ぼす \\ イソプロチオランの影響（I）プロトプラストの細胞壁再生*
}

\begin{abstract}
Effects of isoprothiolane (IPT) on the regeneration process of protoplasts isolated from hyphae of Pyricularia oryzae Cav. were examined by electron, phase-contrast and fluorescence microscopies. Electron microscopy revealed that freshly-prepared protoplasts were completely devoid of cell wall. The plasmalemma became corrugated, and small, vesicle-like protrusions appeared from it before any sign of incipient cell wall regeneration, regardless of the presence or absence of IPT. Electron-dense, particle-like wall materials were deposited on the original protoplasts prior to budding within $2 \mathrm{hr}$ after incubation; they were loosely organized along the plasmalemma and developed to form cell walls of fibrillar structure in controls. The overall features and developmental process of cell walls formed in the presence of $20 \mathrm{ppm}$ IPT were similar to those in controls, whereas cell walls formed in the presence of $50 \mathrm{ppm}$ IPT were thinner and less compact than those of controls. Protoplasts incubated in the regenerating medium formed bud-like protrusions by $2 \mathrm{hr}$ after incubation. Regardless of the presence or absence of IPT they continued to repeat budding-like divisions until $8 \mathrm{hr}$, resulting in chains of budded cells. Normal hyphae arose from either original protoplasts or budded cells in chains at $8 \mathrm{hr}$. By $24 \mathrm{hr}$ after incubation in control solutions nearly $50 \%$ of incubated protoplasts had produced hyphae. However, hyphae arose from only $1 \%$ of protoplasts in $20 \mathrm{ppm}$ IPT and were never produced in $50 \mathrm{ppm}$, even after 24 hr. IPT evidently interfered with cell wall regeneration of protoplasts of P.oryzae, but whether the observed effect was the expression of the primary or secondary action of IPT remains uncertain.
\end{abstract}

(Received January 11, 1983)

Key Word : isoprothiolane, Pyricularia oryzae, protoplast, cell wall.

\section{Introduction}

Isoprothiolane (IPT) (diisopropyl-1, 3-dithiolane-2-ylidenemalonate) has been known as a protective and curative systemic fungicide for controlling the rice blast disease caused by Pyricularia oryzae $\mathrm{Cav}^{1)}$. There have been several reports concerning morphological and biochemical effects of this fungicide on the fungus: inhibition of

\footnotetext{
* Contribution No. 59 from the Laboratory of Plant Pathology, Mie University. This work was partially supported by a Grant-in-Aid for Scientific Research No. $56560047(1981,1982)$ from the Ministry of Education and Science of Japan.

** Faculty of Agriculture, Mie University, Tsu 514, Japan 三重大学農学部
} 
appressorial penetration and growth of infection hyphae ${ }^{1,2,11)}$, induction of abnormal swelling of hyphae ${ }^{13)}$, inhibition of the incorporation of ${ }^{14} \mathrm{C}$-sugars into the cell wall ${ }^{14)}$ and of ${ }^{14} \mathrm{C}$-acetate into fatty acids and triglycerides. These earlier papers suggest that IPT may interfere with de novo cell wall synthesis of the fungus. Our preliminary ultrastructural studies on effects of IPT indicated that cell walls of abnormal swellings of P. oryzae hyphae induced by IPT treatment were a little thicker than those of untreated hyphae. However, use of intact hyphae has not provided enough information to allow a conclusion on the mechanism of action of IPT on the fungus. The present study was undertaken to apply IPT to protoplasts prepared from mycelia and to elucidate the effect of IPT on cell wall formation by P. oryzae.

\section{Materials and Methods}

Preparation of protoplasts. Young mycelium of Pyricularia oryzae Cav. (isolate P 2) was obtained from shake cultures incubated at $28 \mathrm{C}$ for $24 \mathrm{hr}$. The mycelium was washed with deionized water three times, then twice with a stabilizing medium $(0.02$ $\mathrm{M}$ phosphate buffer, $\mathrm{pH} 7.0$, containing $0.6 \mathrm{M} \mathrm{KCl}$ and $2 \mathrm{mM} \mathrm{MgCl}_{2}$ ) by centrifugation. The washed mycelium was placed in $\mathrm{L}$-shaped tubes and treated with a mixture of digestive enzymes (cellulase Onozuka $\mathrm{R}-10,20 \mathrm{mg} / \mathrm{ml}$; macerozyme $\mathrm{R}-10,5 \mathrm{mg} / \mathrm{ml}$; zymolyase $5000,7 \mathrm{mg} / \mathrm{ml}$ ) in a stabilizing medium at $30 \mathrm{C}$ with gentle shaking. Protoplasts which were released into the medium were collected by filtration twice through three sheets of J.K. Wiper (Jujo Kimberly, Tokyo) after a 2 hr-incubation. The isolated protoplasts were washed with the stabilizing medium by centrifugation at $1500 \mathrm{rpm}$ for $5 \mathrm{~min}$.

Cell wall regeneration of protoplasts. The purified protoplasts were suspended in a regenerating medium ( $1 \%$ sucrose $; 2.5 \%$ yeast autolysate $; 0.6 \mathrm{M} \mathrm{KCl}$ ). The drops of protoplast suspension were placed on clean cover slips and incubated at $28 \mathrm{C}$. Purified isoprothiolane (IPT) (Nihon Nohyaku Co.) was added to the incubation mixture at at a final concentration of either $20 \mathrm{ppm}$ or $50 \mathrm{ppm}$ at the start of incubation.

Phase-contrast and fluorescence microscopy. A few drops of the protoplast suspension were placed on cover slips for $1,2,4,8$ and $12 \mathrm{hr}$ after incubation, and observed with an Olympus phase-contrast microscope to count the budding cells. To examine the time course of cell wall regeneration of protoplasts, similar preparations were made and stained with $0.1 \%$ calcofluor white (Nihon Kayaku Co.) solution containing $0.6 \mathrm{M} \mathrm{KCl}$ and observed with an Olympus fluorescence microscope $\mathrm{BH}-$ RFL-LB with a Type UV exciter filter (maximum transmission $334 \mathrm{~nm}$ or $365 \mathrm{~nm}$ ) and $435 \mathrm{~nm}$ absorption filter.

Electron microscopy. Specimens for electron microscopy were prepared at the same time as above. The incubated protoplasts were prefixed with a mixture of $5.1 \%$ glutaraldehyde and $4.1 \%$ para-formaldehyde in $0.01 \mathrm{M}$ cacodylate buffer $(\mathrm{pH} 7.4$ ) or $1 \% \mathrm{KMnO}_{4}$ containing $0.6 \mathrm{M} \mathrm{KCl}$, and after washing with deionized water they were postfixed with $1 \% \mathrm{OsO}_{4}$ for $2 \mathrm{hr}$. After dehydration through a graded ethanol series, they were embedded in epoxy resin. Ultrathin sections were stained with uranyl acetate and lead citrate, and observed with a Hitachi $\mathrm{H} 700 \mathrm{H}$ transmission electron microscope. 


\section{Results}

\section{Isolated protoplasts}

Freshly-prepared protoplasts observed with a phase-contrast microscope were globular with varied diameters from 2.5 to $5.5 \mu \mathrm{m}$ (Plate I, 1). Electron microscopy revealed that protoplasts fixed immediately after isolation were devoid of cell walls as illustrated in Plate II, 1 and 2. Protoplasts bounded by the continuous plasmalemma contained the usual organelles such as a nucleus, mitochondria, endoplasmic reticula, ribosomes and vacuoles. When freshly-prepared protoplasts were stained with calcofluor white, which binds specifically to glucan and chitin and makes them fluoresce strongly by illumination with $\mathrm{u} . \mathrm{v}$. light ${ }^{9)}$, they never fluoresced, indicating the absence of wall materials around them. This observation is consistent with the above electron microscopic observation. Thus, the present digestive enzyme system was confirmed to completely remove cell walls.

\section{Cell wall regeneration of protoplasts}

\section{Phase-contrast and fluorescence microscopy}

Incubation in the regeneration medium allowed protoplasts to bud within $2-8 \mathrm{hr}$ regardless of the presence or absence of IPT (Fig. 1). Protoplasts showed dimorphic regeneration patterns-formation of bud-like cells (Plate I, 2, 4, 5) and filamentous hyphae (Plate I, 3). In controls, some protoplasts started to form bud-like protrusions by $4 \mathrm{hr}$ after incubation (Fig. 1, Plate I, 2). They further developed to form chains of spherical cells until $8 \mathrm{hr}$. At around $8 \mathrm{hr}$ hyphae of normal appearance emerged from either original protoplasts or bud-like cells in chains (Plate I, 3). Most protoplasts developed a structure with several budded cells before normal hyphae arose (Plate I, 3). Normal hyphae arose from nearly $50 \%$ of protoplasts in controls by the termination of observation at $24 \mathrm{hr}$. As in controls, some IPT-treated protoplasts started to bud by $4 \mathrm{hr}$ regardless of the concentration of IPT (Plate I, 4, 5). In contrast with controls, hyphae never arose from the $50 \mathrm{ppm}$ IPT-treated protoplasts : they continued to produce spherical cells giving rise to chains of budded cells until the termination of observation at $24 \mathrm{hr}$. However, hyphae arose from nearly $1 \%$ of protoplasts treated with $20 \mathrm{ppm}$ IPT by $24 \mathrm{hr}$. The number of budded cells in chains was less in the $50 \mathrm{ppm}$ IPTtreated protoplasts than in the control and $20 \mathrm{ppm}$ IPT-treated protoplasts (Plate I, $2-5$ ). In controls nearly $80 \%$ of the protoplasts had budded by $8 \mathrm{hr}$, whereas in IPTtreated specimens $65 \%$ and $15 \%$ had budded at 20 and $50 \mathrm{ppm}$, respectively. Rates of budded protoplasts reached nearly $90 \%$ and $75 \%$, respectively, in controls and $20 \mathrm{ppm}$ IPT-treated specimens at $12 \mathrm{hr}$ (Fig. 1). However, at most $40 \%$ of the protoplasts had budded at $12 \mathrm{hr}$ in the presence of $50 \mathrm{ppm}$ IPT. Fifty ppm of IPT evidently affected the budding of protoplasts.

The cell wall regeneration process was observed under the fluorescence microscope after staining samples with calcofluor white. Freshly-prepared protoplasts never fluoresced but after $2 \mathrm{hr}$ of incubation about $30 \%$ of protoplasts showed a weak fluorescence (Fig. 1) that became brighter on longer incubation. Regardless of the presence or absence of IPT, 70-90\% of protoplasts already fluoresced by $12 \mathrm{hr}$. As indicated in Plate I, 2-9, original protoplasts and several budded cells near the original 


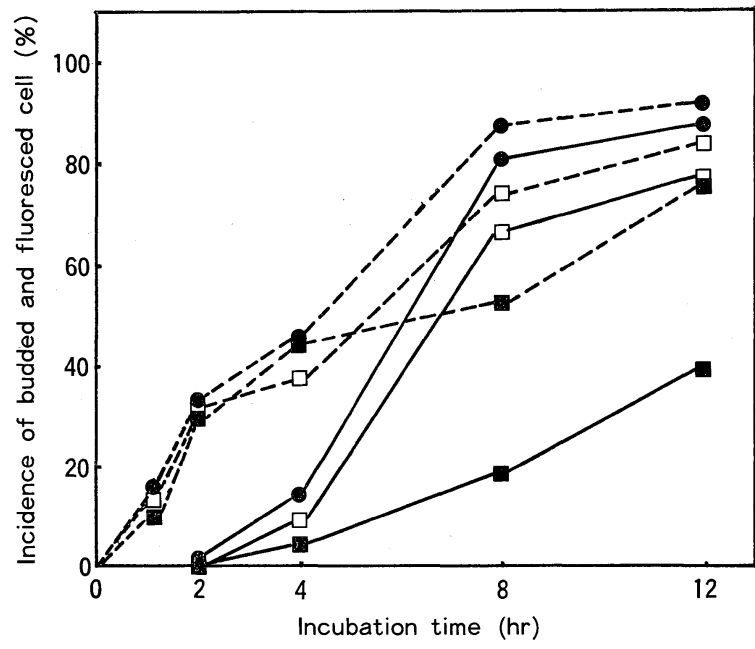

Fig. 1. Effect of isoprothiolane on the incidence of protoplasts fluorescing by the calcofluor white stain and budding of $P$.oryzae during regeneration. (O), control; ( $\square), 20 \mathrm{ppm}$ IPT ; ( $), 50$ ppm IPT ; $(\cdots \cdots)$, fluorescence ; $(-)$, budding protoplasts fluoresced strongly but the intensity of fluorescence was reduced towards the tip of chain of budded cells. The tip of normal hyphae arising from budded cells generally fluoresced more strongly than the rest of the hyphae (Plate I, 7).

2. Electron microscopy

In specimens fixed after $2 \mathrm{hr}$ of incubation, plasmalemma was corrugated and occasionally a number of small protrusions appeared from them regardless of the presence or absence of IPT(Plate II, 3, arrowś). These protrusions were occasionally pinched off from the plasmalemma to form 'subprotoplasts' as defined by Gibsons and Peberdy ${ }^{8)}$. At this stage, amorphous spaces unbounded

by any membranes were observed in the cytoplasm of protoplasts (Plate II, 3). These spaces were located near the plasmalemma. Electron-dense, particle-like wall materials appeared outside the plasmalemma in control specimens fixed $4 \mathrm{hr}$ after incubation (Plate II, 4). Such particle-like layers of variable depth seemed to represent an initial profile of cell wall formation. In control specimens fixed at $12 \mathrm{hr}$, fibrous, electron-dense coats were observed around original protoplasts and budded cells (Plate II, 5, 6). In these coats several electron-dense fibers were loosely oriented parallel to the plasmalemma. However, in general the walls appeared much less compact than those of intact hyphae. In the IPT-treated specimens fixed at $12 \mathrm{hr}$, cell walls had formed outside the plasmalemma (Plate II, 7-9). When protoplasts were treated with $20 \mathrm{ppm}$ IPT, profiles of cell walls were very similar to those of controls. However, cell wall material of $50 \mathrm{ppm}$-treated specimens was sparser and less compact than that of controls. The walls often varied considerably in thickness and appeared to consist of loose aggregates of fine particles with irregular outlines (Plate II, 7-9).

\section{Discussion}

Araki and Miyagi ${ }^{1,2)}$ reported that the effect of IPT on the infection process of $P$. oryzae was expressed as the inhibition of penetration and growth of infection hyphae at $2 \mathrm{ppm}$. Furthermore, Hirooka et al. ${ }^{11)}$ demonstrated by scanning electron microscopy that formation of penetration pegs from appressoria was completely inhibited at $10 \mathrm{ppm}$. It was indicated in the present study that the regeneration of cell walls of protoplasts was evidently affected by the presence of $50 \mathrm{ppm}$ IPT. The earlier reports and the present results suggest that IPT may affect de novo cell wall synthesis in P.oryzae. Kakiki and Misato ${ }^{13)}$ reported that $50 \mathrm{ppm}$ of IPT strongly inhibited the incorporation 
of ${ }^{14} \mathrm{C}$-sugars, but not of ${ }^{14} \mathrm{C}$-glucosamine, into cell walls of $P$. oryzae. Therefore, it is plausible that such a physiological, inhibitory effect of IPT may be related with interference of cell wall synthesis which was observed by the present cytological means. The calcofluor white stain indicated that wall materials were, nevertheless, deposited outside the plasmalemma, even in the presence of $50 \mathrm{ppm}$ IPT. However, electron microscopy revealed that cell wall materials of $50 \mathrm{ppm}$-treated protoplasts were reduced in quantity and less well-organized than those of controls. These observations suggest that IPT may have an inhibitory effect on the deposition of wall materials, which is normally followed by the progressive organization of wall materials into cell walls of a compact appearance.

Recently, a number of cytological studies have been conducted on the regeneration of protoplasts from various fungi ${ }^{8,10,12,15,16)}$. The initial sign of growth of regenerated protoplasts as bud-like protrusions is very common in fungi, e.g. Fusarium culmorum $^{6}$, P. oryzae ${ }^{17)}$, Neurospora crassa ${ }^{3)}$, Geotrichum candidum ${ }^{5)}$ and Alternaria kikuchiana ${ }^{15)}$. Although the reason why the bud-like growth occurs at the early stage of regeneration is unknown at present, it is plausible that it may be due to an imbalance in the ratio between cell volume and cell wall materials during the initial stage of growth. As mentioned above, $50 \mathrm{ppm}$ IPT interferes with cell wall regeneration by protoplasts. Moreover, the number of budded cells formed from one original protoplast was less at $50 \mathrm{ppm}$ than in controls, whereas the presence of IPT did not remarkably affect the volume of individual budded cells. Therefore, it is likely that when protoplasts are in contact with $50 \mathrm{ppm}$ IPT, the rate and/or quantity of increase of cell volume may exceed that of cell wall synthesis, and budding-like divisions may be repeated, resulting in no normal hyphae being formed. On the contrary, it is considered that in controls the increase of cell volume and cell wall synthesis may reach an equilibrium, allowing formation of normal hyphae within $8 \mathrm{hr}$ of incubation. A similar effect of other fungicides on the inhibition of emergence of normal hyphae from protoplasts was reported in Botrytis cinerea treated with N-(3',5'-dichlorophenyl)-1, 2-dimethylcyclopropane-1, 2-dicarboximide ${ }^{12)}$ and Alternaria kikuchiana treated with polyoxin ${ }^{15}$.

Calcofluor white has been used by biologists to localize cellulose, chitin and other glucans, because of its ability to form hydrogen bonds specifically with $\beta-1,4$ and $\beta-1,3$ polysaccharides ${ }^{4,5,9,15,16)}$. Sietsma and De Boer ${ }^{16)}$ and Kohno et al. ${ }^{15}$ ) demonstrated by the calcofluor white stain that freshly-prepared protoplasts, respectively, Pythium sp. and Alternaria kikuchiana did not fluoresce at all, but after 1-2 hr incubation in the regenerating medium most of them showed weak fluorescence that rapidly became brighter up on longer incubation. Their observation is quite consistent with the present data indicated in Fig. 1. Cell walls were regenerated from the original protoplasts prior to the protrusion of budded cells, as indicated by electron microscopy in P.oryzae ${ }^{17}$ ) and Alternaria kikuchiana ${ }^{15}$. In the present study, the calcofluor white stain gave extremely intense fluorescence over the entire surfaces of original protoplasts prior to budding and also at the apex of control hyphae which were formed later. Electron microscopy revealed that cell wall materials regenerated around the protoplasts, especially at $50 \mathrm{ppm}$, were loosely-aggregated and thus dissimilar to those of intact hyphae, which usually consisted of compact inner, (middle) and outer layers. Thus, calcofluor white may have specificity to loosely-woven wall materials rather than to 
well-organized, intact cell walls. This speculation is supported by the fact that intact mycelium gives a weak fluorescence by the calcofluor white stain. The present results using electron microscopy and calcofluor white stain would suggest that cell walls regenerated around protoplasts may not be identical to those of intact hyphae in structure and even in composition. This seems to be the case at least at the early stage of regeneration, while protoplasts repeat budding. Therefore, we should note the possibility that the above-mentioned effect of IPT might apply only to the protoplast and not to intact mycleium. Further studies should be done concerning this point before we make a firmer conclusion.

\section{Acknowledgements}

We are indebted to Dr. James R. Aist, Cornell University, for correcting the English in the text.

\section{Literature cited}

1. Araki, F. and Miyagi, Y. (1976). Ann. Phytopath. Soc. Japan 42: 401-406.

2. Araki, F. and Miyagi, Y. (1977). J. Pestic. Sci. 2: 457-461.

3. Bachmann, B. J. and Bonner, D. M. (1959). J. Bacteriol. 78: 550-556.

4. Darken, M. A. (1962). Appl. Microbiol. 10: 387-393.

5. Dooijewaard-Kloorterziel, A. M. P., Sietsma, J. M. and Wouters, J. M. (1973). J. gen. Microbiol. 74: 205-209.

6. Garcia-Acha, I., Lopez-Belmonte, F. and Villanneva, J. R. (1966). Ibid. 45: 515-523.

7. Gibson, R. K., Burckley, C.E. and Peberdy, J.F. (1976). Protoplasma 89: 381-387.

8. Gibson, R. K. and Peberdy, J.F. (1972). J. gen. Microbiol. 72: 529-538.

9. Haigler, C. H., Brown, R. M. Jr. and Benziman, M. (1980). Science 210: 903-906.

10. Hashiba, T. and Yamada, M. (1982). Phytopathology $72: 849-853$.

11. Hirooka, T., Miyagi, T., Araki, F., Kunoh, H. and Ishizaki, H. (1982). Pestic. Sci. 13: 379-386.

12. Hisada, Y. and Kawase, Y. (1977). Ann. Phytopath. Soc. Japan 43: 151-158.

13. Kakiki, K. and Misato, T. (1979). J. Pestic. Sci. 4: 129-135.

14. Kakiki, K. and Misato, T.(1979). Ibid. 4: 305-313.

15. Kohno, M., Tanaka, H., Ishizaki, H. and Kunoh, H. (1983). Ann. Phytopath. Soc. Japan (Submitted for publication).

16. Sietsma, J. H. and de Boer, W. R. (1973). J. gen. Microbiol. 74: 211-217.

17. Tanaka, H., Ogasawara, N. and Kamimiya, S. (1981). Agric. Biol. Chem. 45: 1541-1552. 
和文摘要

\author{
イネいもち病菌に及ぼすイソプロチオランの影響（I） \\ プロトプラストの細胞壁再生
}

石崎 寛・矢島 明・河野 満・久能 均

\begin{abstract}
イネいもち病菌々采から調製したプロトプラストの細胞壁再生過程に及ぼすイソプロチオラン (IPT) の影 響を位相差，溃光，電子顕微鏡によって検討した。IPT の有無にかかわらず，プロトプラストは再生処理後 2 時間以内に出芽状の分裂を始め, 以後同様の分裂をくり過し，連鎖状の膨潤細胞群となった。対照区では， 8 時間までにこの細胞群から系状の菌采が伸長し始め, 24 時間まで約 $50 \%$ のプロプラストから菌系が伸

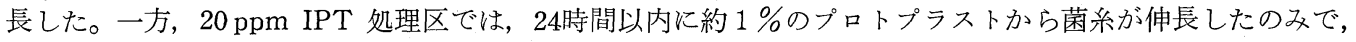
$50 \mathrm{ppm}$ 処理区では菌系伸長は全く認められなかった。また, $50 \mathrm{ppm}$ 処理は細胞分裂を強く阻害した。カル コフロール染色試料の螢光顕微鏡観察は, IPT の有無にかかわらず，細胞分裂に先立って細胞壁成分が沈着 することを示唆した。電子顕微鏡観察によると, 対照区では高電子密度の粒子状の壁成分が再生処理後 2 時 間以内に細胞膜外表面に沈着し始め，12時間以内に $0.7 \sim 0.8 \mu \mathrm{m}$ の細胞壁が再生された。この細胞壁は正常 な菌系のそ北とは異なり，粒状ないしは繊維状の壁成分がゆるやか飞配列した状態で，外層・内層の区別る 認められなかった。20 ppm 処理区の再生細胞壁の様相は, 対照区のそれとほぼ同じであったが, 50 ppm 区 では，壁成分がわずかに細胞膜外表面に沈着したのみで，対照区ほど顕著な細胞壁は再生されなかった。以 上の結果, $20 \mathrm{ppm}$ 以上の IPT は, 再生プロトプラストからの正常菌系の伸長を阻害し, $50 \mathrm{ppm} \mathrm{IPT}$ は細胞 壁再生過程，特に壁成分の合成に影響を及ぼすことが明らかになったが，これらの作用が一次的作用か二次 的作用であるかは今後検討する必要がある。
\end{abstract}

\title{
Explanation of Plates
}

Plate I. Phase-contrast (1-5) and fluorescence microscopy (6-9) of the regeneration process of protoplasts. Bar $=10 \mu \mathrm{m}$.

1. Freshly-prepared protoplasts have diameters from 2.5 to $5.5 \mu \mathrm{m}$.

2. A chain of budded cells emerging from the original protoplast (arrow), incubated for $8 \mathrm{hr}$ in the regeneration medium containing no IPT.

3. A hypha (arrow) arising from a control protoplast after $12 \mathrm{hr}$ of incubation.

4. A chain of budded cells emerging from the original protoplast incubated for $12 \mathrm{hr}$ in the regeneration medium containing $20 \mathrm{ppm}$ IPT.

5. A short chain of budded cells formed in the presence of $50 \mathrm{ppm}$ IPT during $12 \mathrm{hr}$ incubation.

6. A budded-cell chain arising from the original protoplast (arrow) in a control after $8 \mathrm{hr}$ incubation. Stained with calcofluor white. Note that the original protoplast and the budded cells near it fluoresce strongly and that the intensity of fluorescence is progressively less towards the tip of the chain.

7. A hypha arising from a budded-cell chain after $12 \mathrm{hr}$ incubation in the control regeneration medium. Note that the apex of the hypha fluoresces much more strongly than does the rest of the hypha.

8. A budded-cell chain formed in $20 \mathrm{ppm}$ IPT during a $12 \mathrm{hr}$ incubation. The cell near the apex fluoresces less strongly than the other cells in the chain.

9. A short chain of budded cells formed during the $50 \mathrm{ppm}$ IPT treatment for $12 \mathrm{hr}$. The calcofluor white stain indicates that cell walls have been formed by all the cells. However, normal hyphae never arise from the chain under these conditions.

Plate II. Electron microscopy (1-3: glutaraldehyde-formaldehyde- $\mathrm{OsO}_{4}$ fixation ; 4-9: $\mathrm{KMnO}_{4}-\mathrm{OsO}_{4}$ fixation)

1. A freshly-prepared protoplast, devoid of a cell wall. A nucleus (n), endoplasmic reticula (er) and a vacuole (v) are visible in the cytoplasm. Bar $=1 \mu \mathrm{m}$.

2. An enlarged portion of a freshly-prepared protoplast bounded by a smooth plasmalemma $(\mathrm{pm})$. A nucleus, mitochondria $(\mathrm{m})$ and abundant ribosomes are visible in the cytoplasm. 
$\mathrm{Bar}=0.5 \mu \mathrm{m}$.

3. A control protoplast after $2 \mathrm{hr}$ incubation. The plasmalemma is corrugated and several protrusions of the plasmalemma (arrows) are present at this stage. Electron-lucent, amorphous, unbounded spaces (as) appear in the cytoplasm near the plasmalemma. Bar $=1 \mu \mathrm{m}$.

4. Wall materials of fine, particle-like appearance have been deposited outside the plasmalemma of a control protoplast during a $4 \mathrm{hr}$ incubation. Bar $=0.5 \mu \mathrm{m}$.

5. A cell wall (cw) had formed around the budded cells in a control preparation during a 12 hr incubation. Bar $=1 \mu \mathrm{m}$.

6. A cell wall around the control protoplast after $12 \mathrm{hr}$ of incubation. The cell wall consists of aggregated, particle-like wall-materials and several, thin, electron-dense, fibrillar structures. The overall appearance is heterogenous and loosely-aggregated. Bar $=1 \mu \mathrm{m}$.

7. Budded cells surrounded by a loosely-aggregated cell wall in the $50 \mathrm{ppm}$ IPT treatment for $12 \mathrm{hr}$. Bar $=1 \mu \mathrm{m}$.

8. A cell wall formed in the $50 \mathrm{ppm}$ IPT-treated specimen during $12 \mathrm{hr}$ of incubation. The cell wall consists of loosely-aggregated, fine particles and fibrous, layerd structures. Bar $=1 \mu \mathrm{m}$.

9. A cell wall of varied depth and heterogenity formed in regeneration medium containing 50 ppm IPT during $12 \mathrm{hr}$ of incubation. Bar $=1 \mu \mathrm{m}$. 


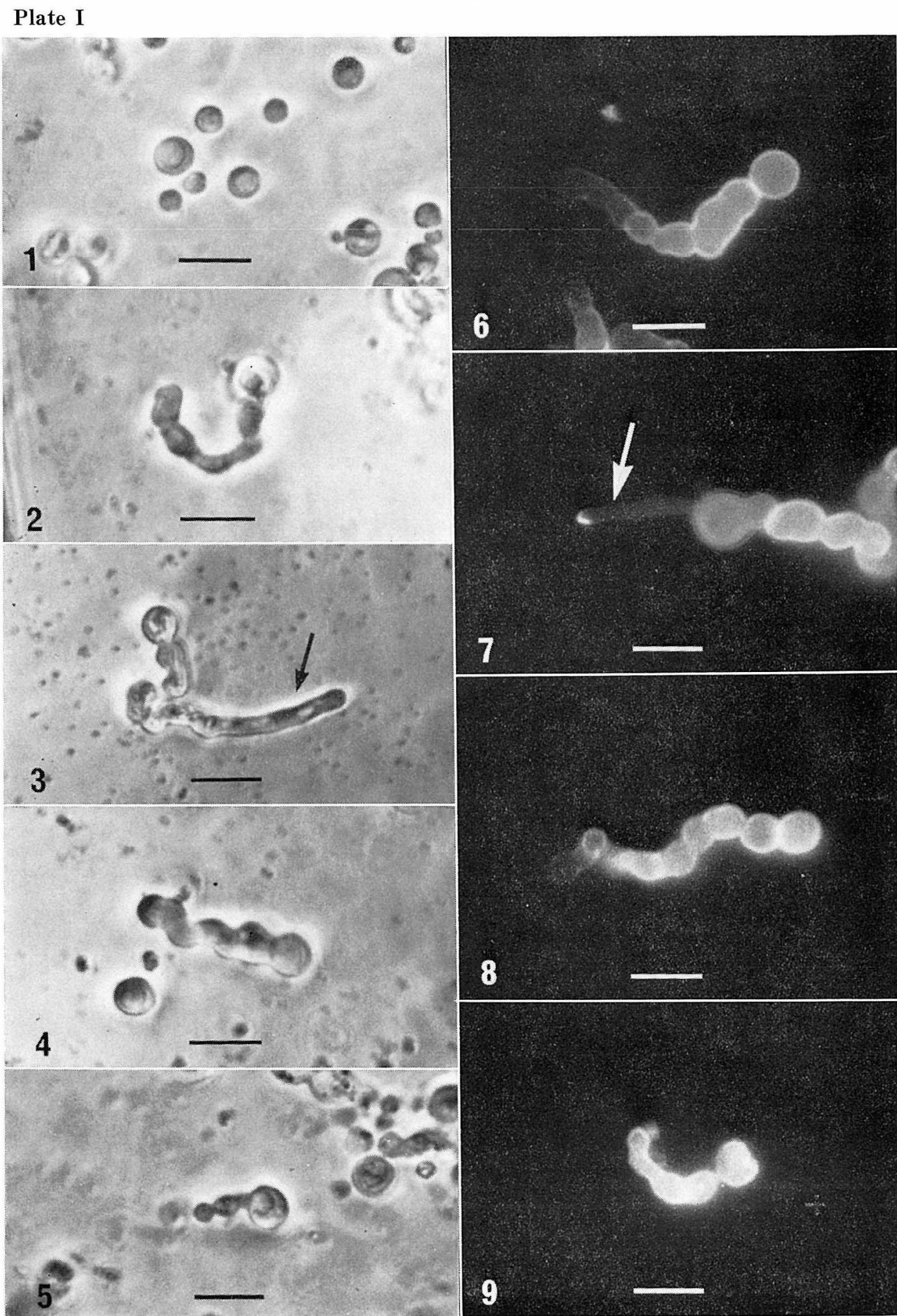


Plate II

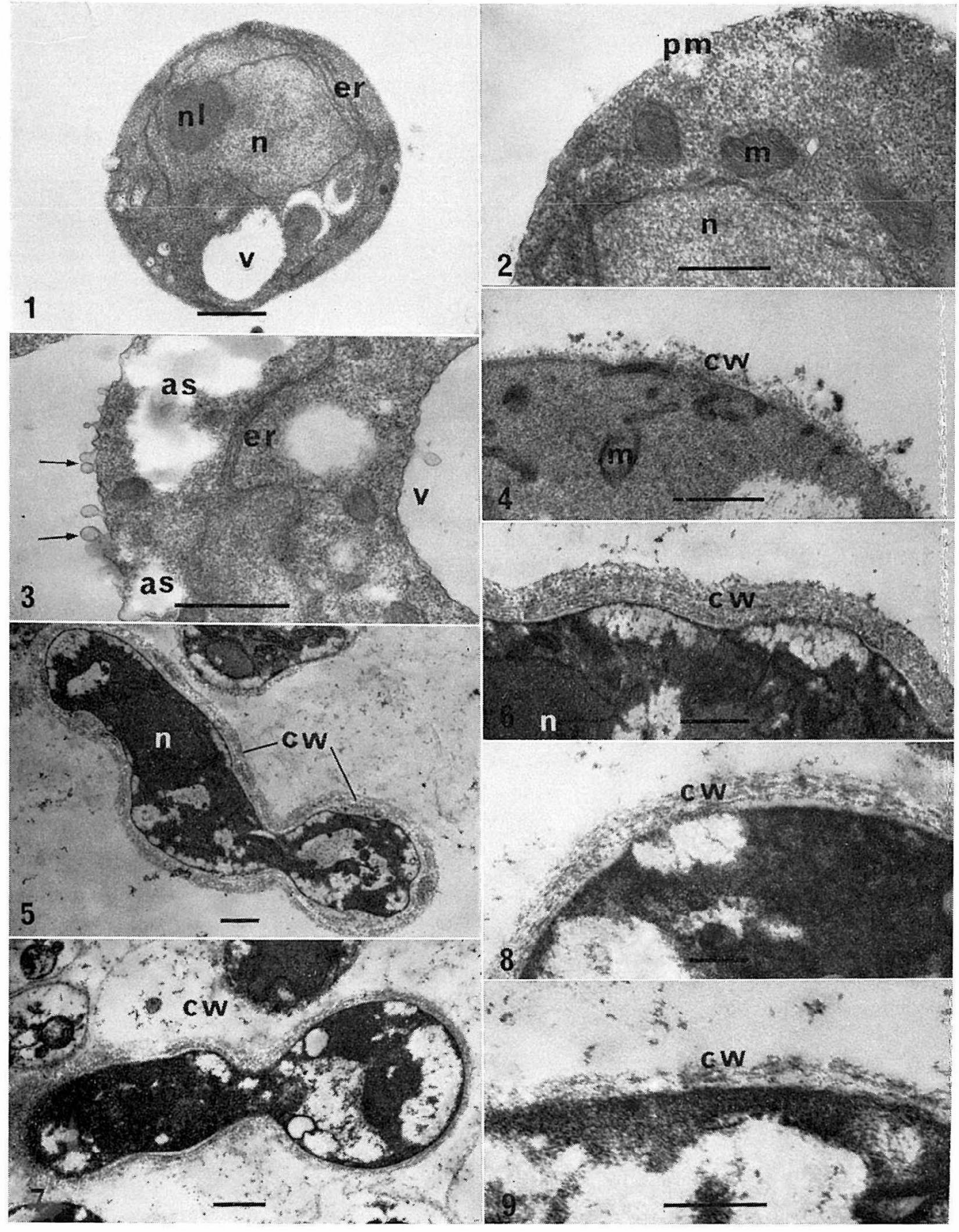

